\title{
Analysis of Socio - Economic Characteristics of Rice Consumer's in Adamawa State, Nigeria
}

\author{
Gabul, P.*; Hamid, M.Y.; Jafar-Furo, M.R.
}

Department of Agricultural Economics and Extension, Adamawa State University, Mubi, P. M. B. 25 Mubi, Adamawa State, Nigeria. *Corresponding Author

Received: 06 Nov 2020; Received in revised form: 27 Dec 2020; Accepted: 03 Jan 2021; Available online: 12 Jan 2021 (C)2021 The Author(s). Published by The Shillonga Publication. This is an open access article under the CC BY license (https://creativecommons.org/licenses/by/4.0/).

\begin{abstract}
The study analyzed socio - economic characteristics of rice consumers in Adamawa State Nigeria. The population of the study involved all the households in Adamawa State. However, the research used a sample size of 128 House Hold Heads (HHHs) for the work. Primary data was generated from the respondents through a well-structured questionnaire, but only 120 questionnaires were retrieved and successfully analyzed to accomplish the study. Descriptive statistics, frequencies and percentages were used to describe the socio-economic characteristics of rice consumers in the state. The result revealed that, majority (62.5\%) of the respondents are males, majority (39.1\%) aged between 31-40 years and majority $(87.5 \%)$ were married, majority (50.83\%) attended post- secondary education, majority (37.5\%) had 6-10 members in their household and majority (41.7\%) are engaged in business as major source of livelihood. It also showed that majority (40\%) earned at least $\$ 50$, 000 monthly. Similarly, majority (62.5\%) spent $\$ 20$, 000 monthly on rice. It also revealed that most of the respondents consumed rice on daily basis and purchased up to $25 \mathrm{~kg}$ per month. The paper reveals that, rice consumers in the area were younger, married, had moderate family size, they are literate, and majority belong to business class and earning moderate income. The study therefore concludes that rice consumption is promising in the area evident from the consumer's income and monthly expenditure on rice. Despite the great demand potential for rice in the area, it is recommended that, sensitization campaigns on improve patronage of home grown and processed rice will go a long way in increasing the demand for domestic rice.
\end{abstract}

Keywords-Analysis, Local, Rice, Consumer's, Characteristics.

\section{INTRODUCTION}

Rice is an important annual crop in Nigeria been one of the major staples, which can provide a nation's population with the nationally required food security minimum of 2,400 calories per person per day according to Food and Agricultural Organization (FAO, 2014). The average Nigerian consumes $24.8 \mathrm{~kg}$ of rice per year, representing 9 per cent of annual calorie intake International Rice Research Institute (IRRI, 2011). Due to its increasing contribution to the per capita calorie consumption of Nigerians, the demand for rice has been increasing at a much faster rate than domestic production and more than in any other African countries since mid-1970s (FAO, 2014). For instance, during the 1960s, Nigeria had the lowest per capita annual consumption of rice in the West African sub-region with an annual average of $3 \mathrm{~kg}$. Coincidentally, that was the time when Nigerian was selfsufficient in both production and consumption. Since then,
Nigeria's per capital consumption levels have grown significantly at 7.3 per cent per annum. Consequently, per capital consumption during the 1980 s increased to an annual average of $18 \mathrm{~kg}$ and reached $22 \mathrm{~kg}$ between 1995 2000 and 38kg between 2010 and 2016 (FAO, 2017).

The fact that, rice is consumed globally by at least half of the world population which according to Oyinbo et al., (2013) was estimated to about 5 Billion residing in about 176 countries with different consumption patterns and requirements due to various socio - economic characteristics such as: age, gender, educational background, family size, occupation, income levels and expenditure patterns. The above-mentioned variables might be important in guiding the type and quantity of a commodity to be supplied and demanded and this invariably, will help in planning and policy decisions. Studies conducted on socio -economic characteristics in the other parts of the world were found to be good 
determinants of consumption for instance (Zul Ariff, 2007, Ogundele, 2014) conducted a research on consumer preference for rice in Kelantan, Malaysia, he reported that, socio - demographic factors and physical factors show a relationship to local rice. The result revealed that, age, educational level, marital status, gender, and occupation of consumer have a significant impact on consumer preference for local rice. Similarly, Mhlanga, (2010), conducted a research in Benin Republic on economic analysis of consumer based attributes for rice. He found that socio- economic factors are not important in consumer purchasing decision.

Accordingly, Nigeria, which is highly populated with an estimated population of over 200 Million people, spread across 36 states and Federal Capital Territory (FCT), with six Geo - Political and seven hundred and seventy four (774) Local Government Areas (LGAs). One should expect diversity across so many issues including agricultural commodities consumption. For instance, a particular food item might be highly demanded due to certain factors in one area and little of it might be demanded elsewhere because of other factors. Therefore, any efforts to studying socio - economic factors and how they determine consumption is desirable and this constitute the background of this study analysis of socio - economic characteristics of rice consumers in Adamawa state Nigeria. Therefore, in an attempt to understand how some factors influence rice consumption in the area, the researcher provided answer to; what are the socio economic characteristics of rice consumers in Adamawa state, Nigeria. The answers might be relevant to existing and potential rice actor, policy makers and development planners in taking decision.

\section{Objective of the Study}

The specific objective of the study was to analyze socio economic characteristics of rice consumers in Adamawa state, Nigeria.

\section{MATERIALS AND METHOD}

\section{The Study Area}

Adamawa State is located on latitude $7^{\circ}$ and $11^{\circ} \mathrm{N}$ and Longitude $11^{\circ}$ and $14^{\circ} \mathrm{E}$. It shares boundary with Taraba State in the south and west, Gombe State in its North-west and Borno State to the North. The State has an international boundary with the Cameroon Republic along its eastern side. It has a land area of about $38,741 \mathrm{~km}^{2}$ (Adebayo, 1999). The State is divided into 21 Local Government areas and has a tropical wet and dry climate with dry season period ranging from November-March while the wet season spans April to October (Adebayo, 1997).

Agriculture is the mainstay of about $80 \%$ of the inhabitants of the State and the ecological condition of the State permits cultivation of root crops, cereals and rearing of livestock in large numbers.

Maximum temperature might reach as high as $40^{\circ} \mathrm{C}$ especially between March and April with a minimum temperature as low as $18^{\circ} \mathrm{C}$ between December and January. This temperature range is good for rice enterprise especially during grain formation and during drying after parboiling among small scale rice millers. The relative humidity between January and March ranges from 20-30\% and reached a peak of $80 \%$ in August and September (Adebayo, 1997).

The mean annual rainfall is about $1000 \mathrm{~mm}$, which allow the cultivation of rice and other crop such as ground nut, guinea corn, cowpea and vegetable of different kinds (Adebayo, 1997).

\section{Sampling Techniques}

Multi stage, purposive and simple random sampling techniques were used for the study. The first stage involved consideration of the four (4) Agricultural zones demarcated by Adamawa State Agricultural Development Project (ADP) Namely, Zone I, II. I11 and 1V respectively. The second stage involved purposive selection of two (2) Local Government Areas (LGAs) from each zone making a total of eight (8) LGAs. The third stage involved purposive selection of one (1) Urban/ Peri Urban wards and one (1) rural ward (settlements) from each LGA which gave a total of 16 wards in the state. The fourth stage involved collection of lists of households in each of the ward from the districts head office which serve as the sampling frame. The last stage involved simple random selection of 8 households' heads from the 16 wards according to the list collected (sampling frame). Finally, a total of 128 respondents were obtained as the sample size. The sampling distribution of the respondents is presented below: 
Table 1: Showing sampling distribution of respondents according to zones, local government areas and wards

\begin{tabular}{cclcc} 
Zones & Local Government Areas & Wards & Households & Sample Households Heads \\
\hline Zone I & Mubi - North & Yelwa & 419 & 8 \\
& & Mayo - bani & 97 & 8 \\
& \multirow{2}{*}{ Mubi - South } & Nassarawo & 274 & 8 \\
& & Mujjara & 142 & 8 \\
\multirow{2}{*}{ Zone II } & \multirow{2}{*}{ Gombi } & Gombi -North & 149 & 8 \\
& & Garkida & 55 & 8 \\
& \multirow{2}{*}{ Song } & Song Gari & 240 & 8 \\
\multirow{3}{*}{ Zone III } & \multirow{2}{*}{ Yola- south } & Zumo & 106 & 8 \\
& & Adarawo & 188 & 8 \\
& \multirow{2}{*}{ Fufore } & Ngurore & 336 & 8 \\
& & Fufore & 562 & 8 \\
\multirow{2}{*}{ Zone IV } & \multirow{2}{*}{ Numan } & Ribadu & 119 & 8 \\
& \multirow{2}{*}{ Lamurde } & Numan & 319 & 8 \\
& & Imburu & 68 & 8 \\
& \multirow{2}{*}{ Total } & Lafiya & 119 & 8 \\
& & Gyawana & 180 & 8 \\
& & & $\mathbf{3 , 3 7 3}$ & $\mathbf{1 2 8}$
\end{tabular}

\section{Source: Field survey, 2019}

\section{Data Collection}

Data for the study was generated from primary source. Primary data was collected from rice consumers identified at the household's level through the use of structured questionnaire administered to Households Heads. The survey questionnaire was designed to gather information on the socio-economic characteristics of the respondents including, age, education, gender, income, household size, marital status and household expenditure.

\section{Data Analyses}

Data collected was subjected to descriptive analyses. Descriptive statistics used were means, frequency count, and percentages. Descriptive statistics as scientific methods for collecting, summarizing, presenting and analyzing data was utilized in drawing valid conclusions and making reasonable decisions based on the results from the data analyzed.

\section{RESULTS AND DISCUSSION}

Socio-Economic Characteristic of Local and Imported Rice Consumers

The socio economic characteristics considered includes; sex, age, educational background, working status, monthly income, and weekly spending on rice.

\section{Gender of the respondents}

Table 2: Presents result on the sex distribution of the respondents. It found that majority (62.5\%) of the respondents are male while the remaining $37.5 \%$ are females. This showed that most of the respondents are males.

Table 2: Gender distribution of the respondents

\begin{tabular}{lcc}
\hline Gender & Frequency & Percentage (\%) \\
\hline Male & 75 & 62.5 \\
Female & 45 & 37.5 \\
Total & $\mathbf{1 2 0}$ & $\mathbf{1 0 0}$ \\
\hline
\end{tabular}

Source: Field survey, 2019 
This implied that males dominate as households heads (HHHs) in the area. This does not necessarily mean that males consume more rice than the females in the communities surveyed, but could be due to the fact that, the male folk hold are responsible for taking care of the family in the area which might be due to religious doctrines and culture where females are mostly under purdah. This result is not in agreement with the findings of Oyenemi (2014) who found in his research work that females form greater percentage of his respondents. He further lamented that female headed household are likely to be more conscious of the quality and the combination of different variety of food consumed by the household than males' households. One can therefore deduced that male might likely go for lower quality while females go for higher quality rice.

\section{Age of the respondents}

Table 3: Presents age distribution of the respondent. It found that majority $(39.17 \%)$ of the respondents were between the age of 31 to 40 years while $36.7 \%$ of the respondents were between the age of 41 and 50 years. Similarly, $19.17 \%$ of the respondents were between the age bracket of 21 to 30 years while $5 \%$ of the respondents were 51 years and above.

Table 3: Age distribution of the respondents

\begin{tabular}{lll}
\hline Age & Frequency & Percentage (\%) \\
\hline $21-30$ & 23 & 19.17 \\
$31-40$ & 47 & 39.17 \\
$41-50$ & 44 & 36.7 \\
$51-60$ & 6 & 5 \\
Total & 120 & 100 \\
\hline
\end{tabular}

\section{Source: Field survey, 2019}

This showed that most of the respondents are younger because up to 60 percent fall within the age bracket of 21 to 40 years old. This age bracket constitutes the most active and productive stage and greater percentage of labor force is expected from this category of people. The need for energy supply from food rich in carbohydrates and other nutrients is very important to support work which rice is considered appropriate because of its high energy potentials as reported by Kasali et al. (2010). Similarly, the fact that this age bracket dominate in the study area does not conclude that they are the major consumer's, other factors such as been the major households heads could be the reasons. This result is not in agreement with the findings of Olorunfemi (2014) who found that people of the age of 49 years were the major consumers of rice in his study. However, it is in agreement with Ariff (2017) who conducted a research on preference of consumer towards imported and local rice in Kelantan State, Malaysia and reported that that the largest portion $(50.6 \%)$ of the respondents aged 25 years and below often decided rice purchasing.

\section{Marital status of the respondents}

Table 4: Presents result on the marital status of the respondents. It found that majority $(87.5 \%)$ of the respondents were married, $8.33 \%$ of the respondents were single, while $4.17 \%$ of the respondents were of the category of widows and divorcees.

Table 4: Distribution of the respondents according to marital status

\begin{tabular}{lll}
\hline Marital Status & Frequency & Percentage (\%) \\
\hline Single & 10 & 8.33 \\
Married & 105 & 87.5 \\
Widows & 5 & 4.17 \\
Total & 120 & 100 \\
\hline
\end{tabular}

\section{Source: Field survey, 2019}


This implied that, majority of the respondents were married. However, this does not mean that married people are the ones that consume rice most in Adamawa State. It might be because they are the ones that are usually responsibility to take care of their family. The result is in conformity with the findings of Bamidele et al., (2010) who reported that, married people usually have feeding patterns and cultivate the habit of eating at home as a way of socializing with their family members whereas the unmarried may or may not have any feeding pattern as he/she can choose to eat away from home and the choice of food may be dictated by whatever is available at the eating point. Therefore, marital status will definitely affect decision on the type and the quantity of food to be consumed by most households.

\section{Family size of the respondents}

Table 5: Presents result on the family size of the respondents. It found that majority $(37.5 \%)$ of the respondents had a family size of 6-10 members, $20.0 \%$ of the respondents had 16-20 members, $18.3 \%$ of the respondents had a family size of 11-15 members, whereas $12.5 \%$ of the respondents have more than 20 members while $11.7 \%$ of the respondents had a family size of less than five (5).

Table 5: Distribution of respondents according to family size

\begin{tabular}{lll}
\hline Family Size & Frequency & Percentage (\%) \\
\hline $1-5$ & 14 & 11.7 \\
$6-10$ & 45 & 37.5 \\
$11-15$ & 22 & 18.3 \\
$16-20$ & 24 & 20.0 \\
Above 20 & 15 & 12.5 \\
Total & 120 & 100 \\
\hline
\end{tabular}

\section{Source: Field survey, 2019}

This showed that majority of the respondents had a family size of 6-10 members. Accordingly, it's a general knowledge the larger the family size, the larger the demand for food. This implies that those that had 6-10 members dominate in the state which is considered moderate in term of food requirement. The size of the family is expected to determine the quantity of food to be purchased and to some extent the larger the size the more the decision will be influenced. This could be due to the fact that, the more the members of the family to be feed, the more consumption level. Consequently, larger family size may likely go for cheaper rice than small size family, because of the price and income level. For instance, Diako et al. (2010) and Gideon et al. (2014) reported that larger household size generally tends to buy local rice in order to save money and also household size was positively related with preference for local rice. This is also in consonance with the result obtained by Alfred and Adekayode (2014).

\section{Educational qualification of the respondents}

Table 6: Presents result on educational background of the respondents. It found that majority $(50.83 \%)$ of the respondents had attended tertiary education and obtained either OND, HND or B.Sc., $27.5 \%$ of the respondents had secondary education (SSCE) as their highest qualification, $14.17 \%$ of the respondent had primary certificate as their highest educational qualification, while $7.5 \%$ of the respondents had non-formal education meaning, they did not attend any formal education.

Table 6: Distribution of respondents according to educational background

\begin{tabular}{|c|c|c|}
\hline Educational background & Frequency & Percentage $(\%)$ \\
\hline Non formal Education & 9 & 7.5 \\
\hline Primary & 17 & 14.17 \\
\hline Secondary & 33 & 27.5 \\
\hline Tertiary & 61 & 50.83 \\
\hline Total & 120 & 100 \\
\hline
\end{tabular}

Source: Field survey, 2019 
This implied that majority of respondents are literates. The high literacy rate could be attributed to the facts that, majority of the people in the area accepted western education for long period of time and most had sent their children's to schools. Generally, education is expected to affect one thinking, decision and output. It is expected that the choice of food to be consumed by educated people will be determined by it nutritional value and quality. Therefore, educated people are expected to go for imported rice than the uneducated because of it perceived quality attributes such as; cleanliness, absence of debris, stones and odour. This assertion is in agreement with the findings of Ogazi (2009) who found that the level of education of households has serious implication on the type, and quality of food consumed by the households. A highly educated household head prefers small quantity of variety of food with different nutritional contents to the larger content of low nutritional components.

\section{Working status of the respondents}

Table 7: Presents result on the working status of the respondents. It found that majority $(41.7 \%)$ of the respondents were business men and women, $31.7 \%$ of the respondents were working full-time, $12.5 \%$ of the respondents were part-time workers, $5.83 \%$ of the respondents were retired from the service and $8.33 \%$ of the respondents were in other form of work.

Table 7: Distribution of the respondents according to their occupation

\begin{tabular}{lll}
\hline Occupation & Frequency & Percentage (\%) \\
\hline Business & 50 & 41.7 \\
Working full-time & 38 & 31.7 \\
Working part-time & 15 & 12.5 \\
Retired & 7 & 5.83 \\
Farmers & 10 & 8.33 \\
Total & $\mathbf{1 2 0}$ & $\mathbf{1 0 0}$ \\
\hline
\end{tabular}

Source: Field survey, 2019

This showed that majority of the respondents are engaged into business. Considering the hikes in the prices of consumer's goods where rice is one, the business class are the ones that have the ability and capability to afford rice due to its cost whereas farmers and salary earners cannot afford most especially in Adamawa State where salaries are not paid regularly. This finding is still in agreement with that of Bamidele et al. (2010) in a research work carried out in Niger and Ekiti States, Nigeria who found that people in wage employment do mix and interact with people in the public almost on daily basis and this can influence their food and feeding habit.

\section{Monthly Income of the respondents}

Table 8: Presents result on the monthly income of the respondents. It found that majority (40\%) of the respondents earned $\$ 50,000$ and more than as their monthly income, $29.17 \%$ of the respondents earned between $\$ 21,000$ to $\$ 30,000$ as their monthly income, $19.17 \%$ of the respondents earned less than $\$ 20,000$, as their monthly income, $4.17 \%$ of the respondents earned between $\$ 31,000$ to $\$ 40,000$, while $7.5 \%$ of the respondents earned between $\$ 41,000$ to $\$ 50,000$ as their income.

Table 8: Distribution of the respondents according to their Monthly Income

\begin{tabular}{lcc}
\hline Monthly Income & Frequency & Percentage (\%) \\
\hline$<20,000$ & 23 & 19.17 \\
$21,000-30,000$ & 35 & 29.17 \\
$31,000-40,000$ & 5 & 4.17 \\
$41,000-50,000$ & 9 & 7.5 \\
Above 50,000 & 48 & 40 \\
Total & $\mathbf{1 2 0}$ & $\mathbf{1 0 0}$ \\
\hline
\end{tabular}

Source: Field survey, 2019 
This implied that majority of the respondents earned income of $\$ 50,000$ and above monthly. This shows that they earned moderate income. Opeyemi et al. (2015) reported that majority $(74 \%)$ of the local rice patrons were farmers. Also more $(40 \%)$ of the imported rice patrons were civil servants which is contrary to this study which reveals that majority are businessmen and women.

\section{Weekly Expenditure of respondents on rice purchase}

Table 9: Presents the result on the weekly expenses of respondents on rice. It found that majority $(62.5 \%)$ of the respondents spend less than $\$ 5,000$ on rice weekly, $16.7 \%$ of the respondents spend between $\$ 6,000-10,000$ weekly to buy rice, $10.8 \%$ of the respondents that they spend 11,000-15,000 weekly on rice, $7.5 \%$ of respondents spend $16,000-20,000$ weekly to buy rice and $2.5 \%$ of the respondents also spend $\$ 20,000$ and above weekly to buy rice.

Table 9: Distribution of the respondents according to their Weekly Expenditure on rice

\begin{tabular}{lcc}
\hline Weekly Expenditure on Rice & Frequency & Percentage (\%) \\
\hline $1000-5,000$ & 75 & 62.5 \\
$6,000-10,000$ & 20 & 16.7 \\
$11,000-15,000$ & 13 & 10.8 \\
$16,000-20,000$ & 9 & 7.5 \\
$21,000-30,000$ & 3 & 2.5 \\
Total & $\mathbf{1 2 0}$ & $\mathbf{1 0 0}$ \\
\hline
\end{tabular}

\section{Source: Field survey; 2019}

This implied that $62.5 \%$ of the respondents spend less than $\$ 5,000$ weekly to buy rice. Consequently, since majority earned $\$ 50,000$ which is considered moderate income monthly, spending up to $\$ 20,000$ monthly on rice is an indication they consumed reasonable quantity of rice. Opeyemi et al. (2015) reported that majority (90\% and $48 \%$ ) of the local and imported rice patrons respectively had income range distribution of 50,000 to 100,000 per month. The mean household's income was 12,250 for local rice and 16,130 for imported rice consumers. High percentage (36\% and $34 \%)$ of local and imported rice patrons respectively spend $¥ 2,001$ to $¥ 4,000$ on rice consumption every month. Their findings therefore are not in consonance with this result.

\section{CONCLUSION}

The study reveals that majority of the rice consumers in the area were married and had 6- 10 members in their households. Similarly, they were at their active and productive age, and majorities were educated above secondary levels which could translate to having wisdom and taking good decision on what is good for them without much influence. Similarly, majority were engage in business with moderate income generating capacity. The study therefore concludes that rice consumers in the study area have favorable socio - economic characteristics which could offer them good purchasing power for rice consumption. However, further studies to test the significant of these socio - economics of rice consumers on quantity of rice consumed in the study area will be a welcome development.

\section{RECOMMENDATION}

Sensitization and awareness: There are need to sensitize Nigerians on the need to patronage domestic rice because the advantages are enormous. It will improve the agricultural contribution to Gross Domestic Products (GDP), increase food security, and generate more employment along the rice chain. Similarly, significant amount of money will be saved which could have been used to import rice. This will improve balance of payment, minimize poverty and foster protection against unfavorable policies (fear of threat due to ban/embargo etcetera). This could be achieved through Radio and Television programs.

Price stability/Improvement in income: Income especially in Nigeria is very stable while unnecessary increases in price of commodities are very common. Paid workers constitute the second category of rice consumers next to business operators. The income of paid workers in Nigeria has been constant static for the past ten years while price of commodities within the period has increased by more than $100 \%$. There is need for a corresponding increase in income of workers in other to improve their purchasing power for rice because at the moment as 
curbing strategies they can only reduce the quantity or go for lower quality rice.

\section{REFERENCES}

[1] Adebayo, A. A. and Tukur, A. L. (1999). Climate I: Sunshine, Temperature, Evaporation and Relative humidity in Adamawa State in Maps. Paraclette Publishers, Yola. pp 20-22.

[2] Adebayo. A. A. (1997). The Agro climatology of rice production in Adamawa State Nigeria unpublished $\mathrm{PhD}$. Thesis Department of Geography Federal University of Technology Yola.

[3] Alfred, S. D. Y. and Adekayode, A. B. (2014) Consumers Attitude toward local rice production and consumption.

[4] Ariff. A.Z. (2017). Preference of consumers toward imported and local rice in kelantan Malesiya. International Journal of community development and development and management study.

[5] Asuming-Brempong, S. and Osei-Asare, Y. (2007). African Association of Agricultural Economists (AAAE) imported rice crowded-out domestic rice production in Ghana Conference Proceedings (2007) 91-97.

[6] Bamidele, F. S. A., Bayomi, O. O. and Ester, O. A. (2010) Economic analysis of rice consumption pattern in Nigeria journal of agricultural science and technology.12:-1-11.

[7] Bamidele, D. O. and Ester, O. A. (2010 (2017). Analysis of the Relationships of Factors Affecting Rice Consumption in a Targeted Region in Ekiti - State, Nigeria. Journal of Applied Quantitative Methods 4 (2): 145-153.

[8] Diako, C., Sakyi-Dawson, E., Bediako-Amoa, B., Saalia, F.K. and Manful, J.T. (2010). Consumer Perceptions, Knowlegde and Preferences for Aromatic Rice Types in Ghana. Nature and Science, 8 (12): 12 - 19.

[9] Food and Agriculture Organisation (FAO) (2004). Rome, Italy World Rice. Research Conference 2004 Tsukuba, 5-7.

[10] Food and Agriculture Organisation (FAO) (2006)."International Rice Newsletter." Food and Agriculture Organization vol. 55: Rome, Italy Accessed August to November 2009.

[11] Food and Agriculture Organisation (FAO) (2014). "Food insecurity in the world." Food and Agriculture Organization Statistics Database accessed July to December 2015.

[12] Food and Agriculture Organization (FAO) (2017). Nigeria at a glance. www. fao. Org/nigeria/fao-in-nigeria/nigeriaat-a-glance/en/.

[13] Food and Agriculture Organisation (FAO) (2012). Briefs on Import Surges - Countries No. 5 Ghana: rice, poultry and tomato paste.

[14] Mbalanga, S. (2010). Economic analysis of consumer-based attributes for rice in benin. Unpublished M.sc thesis submitted to Department of Agricultural Economics and Extension, McGill University

[15] Oyinbo, O., Omolehin, R.A. and Abdulsalam, Z. (2013). Households Consumption Preference for Imported and Domestic Rice in Kaduna State, Nigeria: Implication for rice quality. www.patnsukjournal.net/current issue. June
2013; 9(1):29-37 ISSN: 0704-5213 A publication of Nassarawa State University, keffi 